\title{
America: Symptoms of Decline
}

\author{
by Helena Sheehan
}

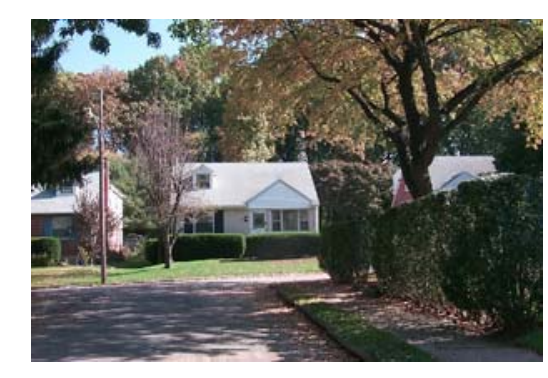

published in The Irish Review 1992

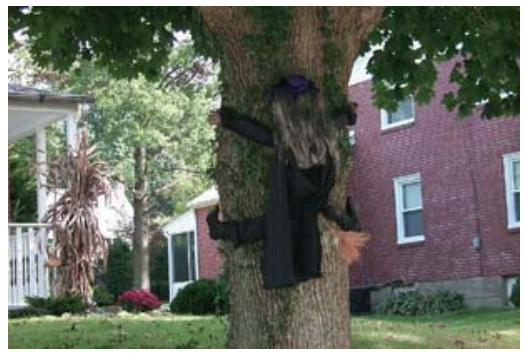

(photos by HS)

America in which I grew up in the 1950 s seemed so strong, so stable, so sure of itself. In the 1960s, this social order was shattered, to a far greater degree than has ever been admitted. It may have been the civil rights movement and then the Vietnam war and then women's liberation which set it off, but a momentum built and swelled into a wave which swept aside all existing assumptions and created an atmosphere in which everything was up for grabs. Peaceful protests turned into increasingly bitter and violent confrontations. It extended into every corner of American society.

By the mid-1970s, the public mood had shifted. The sharp passions of the late1960 s had subsided and settled into a disillusioned alienation that extended even to those who had upheld traditional values against the onslaught of the new left. In post-Vietnam, post-Watergate, post-OPEC America, there was an overwheming sense of a society having lost its way and a longing for reassurance and re-dedication. Its ability to dominate the world and its very belief in its own right to do so had been so deeply undermined as to shake it to its very foundations, however much it persisted in trying to pretend that it was otherwise. In the 1980s came the backlash. It was time to 'lighten up' and to forget about social issues and political problems, or if it was impossible to forget, to turn them over to superheroes to sort out once and for all. It was the era of Dallas and Dynasty and Rambo and Reagan.

Living in Ireland for the past twenty years, I have come to see America in ever sharper relief, in a way I never would have if I had lived there continuously all those years. Having grown up in America also makes me see Ireland in a different way than I would if I had been born here. But being Irish American in this particular way gives me a terrible problem with the whole Irish American scene, from which I have become ever more severely alienated. When I go to America, I want to touch the real America and not a pretend Ireland. I live in the real Ireland, the Ireland of Scrap Saturday and Today-Tonight, and I find the sad shabby delusions of the Shamrock Bars too pathetic to puncture and too much of a distraction from my preoccupation with feeling the pulse of the real America. This was my first time back in ten years and I had so much to do to get a fix on the America of the 1990s. 
There had since been another war. On my way out, Shannon airport was overrun with sunburned US soldiers on their way home from the Gulf. New York was littered with war paraphenalia and the Socialist Scholars Conference I attended there was full of anxiety about the nature of the new world order. Philadelphia, a place which was once home, where I had layers and layers of connection to American society, was where I would try to get to the bottom of what was happening in this society.

The shops were full of all the same sort of 'collateral kitsch' as New York: tshirts with the US flag saying "These colors don't run" and with Bush saying "Read my lips, Saddam" or, if you were thirsty, you could have combat Cooler, a soda in a camoflage can. The country was on a massive "We're Number 1" marketing binge. Flags and yellow ribbons were everywhere. Cherry Hill, New Jersey gave a hero's welcome home to Geoffrey Zahn, the POW we saw on television in abject captivity, of whom locals said "He represents the spirit of this war." Hardly the old John wayne type of all-American hero, this said something about the distance between then and now. This country was desperate for heroes.

The Gulf war was part of every scenario: it came into every conversation, it was a topic on every TV talk show, there was a new local angle in every day's newspaper, the iconography of it was part of every scene the eye surveyed. And yet, the further I got drawn into America, the less real the Gulf seemed. There is something about America which makes the rest of the world seem unreal. It is a society very turned in on itself. The discourse about the Gulf war was far less about the Gulf than about America.

All was not as it seemed here. Beneath the bravado, beneath the massive support for Bush and the Gulf war, there was enormous ambiguity. I asked one of my brothers, a truck driver, what he thought of all the flags and yellow ribbons around Springfield, our suburban home town. He liked them, he said. Did he think the war was right then ? No, he said, he didn't necessarily think that it was right, but he thought that, once it had started and the troops were in there, it had to be supported. Another brother, a high school teacher, took a harsher view: "It was scary. The American people didn't care if it was right or wrong. They just wanted to win." In a Cheers type bar, where my sister is well known, one young male after another came to speak to me out of earshot of the rest to tell me how critical they were of the war, but how difficult it was to stand out. Within homes, people confessed to feeling intimidated about not putting out yellow ribbons.

Writing in the (US) Guardian, the persistent Noam Chomsky, as active against this war as the one in Vietnam, argued that the support for the war was very thin, that skepticism and disbelief were barely below the surface, but that each person felt alone with it, because most had no forms of association which would affirm or mobilise it.

Even within the military, the support was thinner than might be imagined. A US Marine officer, who asked me not to give his name, rank and serial number if I wrote about him, was scathing about the war and the politicians, who were responsible for it, but left ignorant 18 year old kids to deal with it. There was more critical thinking and pacifist feeling in the officer corps of the armed services than anybody realised, he told me. In a postgraduate course on strategic studies for military personnel, much of what was routinely discussed 
would have been considered treasonous 20 years ago, he said. When words like exploitation and colonialism came into the conversation, they came from him, not me.

The country seemed to be riding high, telling itself that it had kicked the Vietnam syndrome, that it was back on centre stage after feeling like a spectator to history during 1989, that it has put Europe and Japan and the 3rd World back in their place. But the victory was hollow and everybody knew it underneath. Already, even before the main victory parade, it had been spoiled by the realisation that there had been no real fight, by the pathetic desolation of the Kurds, by the returning parasitism of the Kuwaitis, by the resentment of veterans of bloody combat in World War II, Korea and Vietnam at the glorification of 'a few days in a sandbox' as a war.

But these things were the least of it. The truth is that, although the us has re-asserted a kind of political and military supremacy and Hollywood has not ceased to assert cultural supremacy, there is no longer the economic base to sustain it. Japan is still buying up Manhattan and Hollywood. The truth is that, as Rev. David Gracie of the American Friends Service Committee said to me, "There is a big vacuum where a sense of national purpose should be". The truth is that it is a society that does not believe in itself in the way it pretends. It is a society in which the symptoms of decline are unmistakable.

The Spring 1991 issue of the US journal Dissent is a special edition on the theme of Social Breakdown in the United States? Signs of Crisis, Symptoms of Decay. Articles outline a scenario featuring the specifics of crime, drugs, AIDS, homelessness, racism, collapse of cities, crisis in education, S\&L scandal, declining productivity, but also more general phenomena such as the dissolution of social bonds and norms, an unprecedented collapse of meaning, a monumental eclipse of hope, a wave of palpable unease spreading across the whole spectrum of American society.

Introducing the theme, Irving Howe writes of a malaise, a sense of things coming apart, of social problems becoming intractable, of a crisis too deep to be corrected by any normal upturn in the economy or quick fix of government intervention. One sign of breakdown he advances is the lack of any consensus on what even constitutes a social problem, let alone a solution. The spurious solutions advanced: 1) to allow the free market to proceed in its majestic mystery, 2) to improve 'character', especially the character of the poor and oppressed, 3) to acquiesce in the sophisticated resignation of 'the limits of social policy', all fail utterly to understand the problem.

The process of breakdown was accelerated in the Reagan years, the years Barbara Ehrenreich refers to as The Worst Years of Our Lives in her new book. Yet, there is a paradox here, Howe argues, as Reaganism brought about a measure of social re-integration, but did so by advancing a set of values (such as extreme individualism, open sanction for acquisitiveness and greed, hostility to the welfare state and trade unions) that are not workable for any length of time in a modern industrial society.

So many symptoms. Authors come at it from all possible angles and the evidence mounts into a fairly compelling case.

The rising popularity of fantasy and the fact that the basic myth of upward mobility is no longer rags-to-riches achievement, but winning the lottery, is, 
according to Jim Chapin, a shift from the psychology of work to the psychology of lotto, a testimony to the irrational side of capitalism and to a deep loss of faith in rationality and in the efficacy of human effort.

Todd Gitlin asks: from where do American Psycho and Die Hard 2 and all the murderous stuff that flows down the channels derive their energy, what is their power? They are beset by a zeitgeist that slashes and burns. They are driven by a cynicism so deep as to defy parody.

But it is not only in the pages of Dissent that you pick this up. It is everywhere. Look at the current crop of American films, for example. Metropolitan, Avalon, Where the Heart Is, to name just the ones I have seen most recently, are pervaded by a strong sense of America having reached its peak and hurling now along a downward curve.

Paul Kennedy's book The Rise and Fall of the Great Powers describes a cyclical process, in which supremacy is established through economic strength, followed by military spending to maintain supremacy, followed by economic decline. The US and USSR are in decline and Europe and Japan are in the ascendant, the argument goes. Barbara Ehrenreich's other recent book Fear of Falling: The Inner Life of the Middle class is another of many recent titles giving expression to various aspects of the economics, politics, sociology and psychology of decline.

Indeed I could detect it on every city street, in every suburban mall, in every family gathering, in every professional encounter, in every newspaper, on every TV show. Walking down Philadelphia's Market street one day, a dirty, drunken, homeless man tumbled about on the sidewalk as I passed. Passing at the same time were a gang of black youths, who argued loudly and abusively with each other for several blocks about whether it was his own fault or not. There was such a sharp edge to the argument, perhaps because none of them could really be sure it mightn't some day be them, because none of them really knew whether they could trust this society that their own best efforts would be enough.

Talking to Americans of all sorts, especially if you probe, reveals an enormous disaffection not far under the surface. Most often it is a list of specific gripes that is combined with a heavy but vague and inarticulate angst that is bigger than all of them.

Pressing further goes along alternative paths. Blaming politicians or reducing large scale sociological problems to small scale psychological ones or simply coming against a wall of impenetrability. I asked one long-time friend, a journalist writing obituaries, what his political philosophy was. "I don't know", he said, "I just know that, when I look around in the world, I don't like much of what I see."

There is still such plenitude. There is so much living space. There are so many gadgets. Yet there is such massive inequality. The top $20 \%$ take in $50 \%$ of the income, whereas the bottom $20 \%$ take in only $3.7 \%$. The $60 \%$ in the middle are full of anxiety about how to hold what they have. The class divide is bound up with all sorts of racial and sexual and generational tensions.

The generational tension is perhaps most symptomatic of decline. There is a sense that the middle generation called 'boomers' (ie, born of the post-war baby boom) are the best educated and most productive, that with them this society has peaked, that they have achieved a standard that not only surpassed their parents, but will not be reached by their children. It expresses itself in various ways. At its most base, there is resentment in relation to the social 
security system, a fear in the middle generation that the older generation, who are living longer, are using up resources that will not be replaced by the younger generation.

The tension is not limited to the dynamics of internal distribution. Deep down, many know that this nation cannot sustain what proportion of the world's wealth that it has been taking. Much of this counrty's sickness, Rev David Gracie said to me, is rooted in "trying to hold on to a lifestyle that is a scandal to the rest of the world."

There is so much that is just so out of kilter here. There is a long-running saga in my own family about a relation who should be committed, but is living on her own, drugged up, a danger to herself and everyone around her the moment she fails to take the drugs. With the trend to de-institutionalisation of mental patients, many are wandering around, destitute and dangerous, on the streets. Side by side with this is the lavish care and attention to the exquisitely tortured psyches of the rich and the psychoanalysis of their dogs.

This does not feel like a society that has won, a society that represents the victory of liberal democracy after the downfall of the alternative system, a society that has proved that it is number one after an easy military victory. How to penetrate this society and understand what makes it tick ? on one level, there is so much distraction, so much chatter, so much clutter. There are so many TV shows, so many things to buy, so many hard-sell can't-fail schemes to get rich, know yourself, find God, lose weight, buy sex by dialing the telephone. There is so much talk about Kitty Kelley's book on Nancy Reagan, about what happened at the Kennedy compound at Easter, about a gay palimony suit against Merv Griffin, about whether the Mets will beat the Phillies.

On another level, can all these be read as clues to the collective psyche? What sort of society is it that throws up the Simpsons and Mutant Teenage Ninja Turtles as its dominant icons? A campy, cynical, childish, desperate society. A society in decline.

These topics and images are nearly all there is left of a common culture and large numbers are utterly alienated from them or relate to them only in a cynical camped-up way. The fact is that, although Americans share a common space, they share less and less in the way of a common culture.

There has been a drastic erosion of civil society. There has been a decline in churches, unions, political organisations, even neighborhoods. "There is no community anymore" I was told again and again. There is less and less public space, even for shopping, which seemed one of the last public places where people came out of their separate private spaces. It is not only the big old city centre department stores that are deserted, but even the suburban shopping malls seem deserted now. Every day piles of catalogues arrive in the post and shopping channels on television parade a never-ending supply of goods that can be ordered by phone and delivered to the door.

Such areas of public space that do still exist are beset with conflict and crisis. Take education. The much discussed 'crisis in education' on one level is anxiety about declining standards, about illiteracy and subliteracy, about abysmal ignorance of basic geography, for example. There are so many levels of irony in the situation. "American students rank near the bottom of the world in skills, but at the very top in self-esteem. Yet our formula for self-improvement is always more self-esteem, not more knowledge. This gives a certain strange quality to discussions of American education." writes Jim Chapin. 
On another level, there is a bitter debate about curriculum in which many of the larger tensions of American society are being played out. Although there never was a centralised education system and therefore no common curriculum in the US, there was nevertheless a common world view underlying its decentralised education systems and there is a pattern in the diverse debate coming in the wake of the challenges to this world view in recent decades.

Basically, the right blames the decline in standards on the left, on the 60 s counter-cultural critique of white, male, Eurocentric (or Amerocentric, more accurately) education and calls for a return to classical texts. Allan Bloom's The Closing of the American Mind was an instant bestseller in this mode. There are complaints about the 'thirdworldisation' of American education and calls for a return to a common culture. There is a backlash against black studies and women's studies and gay studies and peace studies that is part of a more general backlash against anti-racist and anti-sexist and anti-war movements.

The Philadelphia Inquirer, when I was there, carried an article by a final year English student at University of Pennsylvania complaining about the 'DWEMbashing' (ie, Dead White european Males) that she claimed had become the the orthodoxy of her faculty. On many campuses, there is a reaction against what is called "PC" (political correctness) and in many institutions there is a reaction against speech codes banning racist and sexist language and against affirmative action and race and gender quotas. The 'PC' debate currently raging is but the latest episode in a long struggle between the explaining and explained classes.

The left, which has become a force in American society at least within the universities, does not speak with one voice on all issues in this debate over the constitution of knowledge. Many see the absurdities of instructing students on the irrelevance of canonical texts they haven't even read and the convoluted post-structuralist and post-modernist texts that have replaced them. They also see the dangers of an evasive, non-critical and non-communicating pluralism based on the politics of identity. It is a complex debate about how to include excluded voices and how to allow for cultural diversity, without indulging mediocrity and fragmentation; about how to be critical of received tradition and to open it out, while still preserving some sort of a common tradition and a dialogue within it.

Twentysomethings, who have come of age in this flabby anything-goes-world of protean pluralism, complain that they have no bearings, but it is doubtful that any Great Books panacea will bring definition to their diffuse, unfocused, confused selves.

There are so few points of common reference any more. It is becoming less and less possible to talk to anyone who has read the same book or article, heard the same radio programme or even seen the same television programme. It is all so fragmented now. I don't know how anyone watches American TV. It is so broken up into such tiny little bits, with such constant interruption for commercials, that I can't concentrate on it. I found that I actually knew far more about US TV programmes than anyone I met there, but it is very different to watch LA Law or thirtysomething in conditions here, where the same programmes seem far more coherent here than they do there.

Where will it all end? Some, especially if they are coming forth as candidates in the upcoming presidential election, offer hope of some sort of upswing, but the odds are against it. "More likely" Gar Alperovitz argues in The Nation "is a 
continuing trend of decay and failure that will slowly destroy all the old beliefs, leading first to ever deeper disillusionment, then to profound apathy, then to de-legitimation of the existing system, then to anger, and possibly after a long dark winter of discontent, to a demand for something different: for perestroika, for reconstruction, American style."

Perhaps. Or perhaps not.

Website: http://webpages.dcu.ie/ sheehanh/sheehan.htm

E-mail: helena.sheehan@dcu.ie 